\title{
Synthesis, Crystallographic And Electrical Studies of Cobalt Substituted Lithium Hexaferrites.
}

\author{
Suresh. S. Darokar \\ Shri Shivaji Science College, Congress Nagar. Nagpur-12, India. \\ sureshdarokar@gmail.com
}

\begin{abstract}
:
In the present investigation, the samples with substitution of Cobalt and Aluminium in Lithium ferrite ( $\mathrm{M}$ - type ) with the general chemical formula $\mathrm{Li}_{0.5} \mathrm{Fe}_{0.5+\mathrm{x}} \mathrm{Al}_{12-2 \mathrm{X}} \mathrm{Co} \mathrm{xO}_{19}$ were synthesized using reacting oxide by high temperature solid state reaction technique. The structural characterization of compound has been carried out from X-Ray diffraction powder pattern. The compounds are in single hexagonal phase without traces of uncertainly ambiguous reflection. From XRD pattern lattice parameters has recorded with increasing doped aluminum element in the range from $a=5.807 \AA$ to $5.906 \AA$ and $\mathrm{c}=22.507 \AA$ to $22.585 \AA$ pertaining the space group $\mathrm{P}_{3} / \mathrm{mmc}$ (No.194). The mass density of the ferrites were found linearly varies and depends upon the mass and volume of sample.

The X-Ray density has depends upon the lattice constant and molecular weight of the compounds. The average particle size was also estimated. The compounds were studies magnetically by using Guoy's method in the temperature range 300 to $550 \mathrm{~K}$, the result shows that the compounds are paramagnetic in nature.The Curie molar constant was work out.

Key words: Magnetoplumbite, Hexaferrites, Curie molar constant, Seebeck coefficient.etc.
\end{abstract}

\section{Introduction:}

In the family of hexagonal ferrites, the Mangnetoplumbite hexaferrites (MType) created much attention due to wide range of application in industries and created potential to interest in technological and scientific research due to their application importance such as high density magnetic recording, microwave device materials, hard disc in computer system. The application need particularly magnetic and electrical specification with the view, many attempt have been improved the properties of hexagonal ferrites using different tract of additives. The calcium hexferrites [1-6] have magnetic properties comparable to BaM and Sr M. In Calcium ferrites many attempt has been made to replace $\mathrm{Fe}^{+3}$ ions with $\mathrm{Al}^{+3}, \mathrm{Cr}^{+3}$ and $\mathrm{Co}^{+3}$ etc. A compound with the combination of bivalent-tetravalent cation was also used to replace $\mathrm{Fe}^{+3}$ ion such as $\mathrm{Cu}-\mathrm{Ti}$, Co-Ti, Co-Sn, Zn-Sn etc $[7,8]$ without any appreciable change in $\mathrm{BaM}$ structure. When $\mathrm{Fe}^{+3}$ ions are replace by non magnetic ions like $\mathrm{Ti}^{+4}$ and $\mathrm{Sn}^{+4}$ etc. In the same way Lithium ferrites substituted with $\mathrm{Al}$ and Co has been studied structurally, electrically and magnetically [9]. In the present study a series of five sample with chemical formula $\mathrm{Li}_{0.5} \mathrm{Fe}_{0.5+\mathrm{x}} \mathrm{Al}_{12-}$ ${ }_{2 \mathrm{x}} \mathrm{CoxO}_{19}(\mathrm{x}=2,3,4,5$ and 6$)$ were prepared. Lithium ferrites have attracted considerable attention because of the squareness of hysterisis loop coupled with superior temperature performance the crystal structure of M-type like compound with a space group $\mathrm{P}_{3} / \mathrm{mmc}$ (194)can be described as superposition of two structure block namely R-block with composition $\mathrm{BaFe}_{6} \mathrm{O}_{11}$ and $\mathrm{S}$-block with composition $\mathrm{Fe}_{6} \mathrm{O}_{8}[10]$ in the stoichiomatric ratio. 


\section{Experimental:}

All the multicrystalline powder sample were synthesized by high temperature solid state reaction using A.R grade oxides of stoichiomatric ratio $\mathrm{Li}_{2} \mathrm{O}, \mathrm{Fe}_{2} \mathrm{O}_{3}, \mathrm{Al}_{2} \mathrm{O}_{3}$ and $\mathrm{Co}_{2} \mathrm{O}_{3}$ mixture. $\mathrm{Li}_{2} \mathrm{O}$ oxide was carefully dehydrated before the mixing procedure. After grinding the mixture under acetone acid for six hours. During the preparation of pellets of thoroughly grounded mixture in the proper molar ratio with $5 \%$ of PVA as a binder are prepared by applying 10 tone pressure per square inch. These pallets slowly heated in the furnace at $600{ }^{\circ} \mathrm{C}$ for $5-6$ hours to remove binder. Then it was fired at $1200{ }^{\circ} \mathrm{C}$ for 120 hours continuously, after that the furnace were cooled at the rate of $20^{\circ} \mathrm{C}$ per hours up to $1000{ }^{\circ} \mathrm{C}$ and then $50^{\circ} \mathrm{C}$ per hours and then cooled in natural way the phase of final sample were verified by Philips X-ray diffrectometory using N-filter copper radiation. The mean grain size of multicrystalline samples was in the range 150 - $200 \mathrm{~A}^{0}$. All the samples show single phase formation with a space group $\mathrm{P}_{3} / \mathrm{mmc}$ (194). X-ray pattern of the samples as shown in fig. 1.1

The D.C resistivity was measure by the methods using LCR meter /Q meter.[11]. The end faces of pellets were coated with thin layer of conducting silver paste and measurement were made from room temperature to $800 \mathrm{~K}$ Thermoelectric power measurement were carried out after sandwiching the thick pellet between two copper rod from room temperature to $550^{\circ} \mathrm{C}$

\section{Result and discussion:}

In the present work, the Cobalt and Aluminium substituted Lithium hexaferrites were introduced with general formula $\mathrm{Li}{ }_{0.5} \mathrm{Fe}_{0.5+\mathrm{x}} \mathrm{Al}_{12-2 \mathrm{X} \mathrm{CoxO}_{19}}(\mathrm{X}=2,3,4,5$ and 6). The ions in Ba-M compounds can be replaced partly by $\mathrm{Co}^{+3}$ or completely $\mathrm{Li}^{+1}$ and combination of $\mathrm{Fe}^{+3}$ and $\mathrm{Al}^{+3}$ ions without changing the crystal lattice symmetry [12]. In all the specimens substituted ions would be chosen to keep electrical neutrality and to have a similar ionic radii in these ferrites. The Cobalt and Aluminium play an important role in the property variation. XRD technique is used to confirms the formation of hexagonal $\mathrm{M}$ structure of compounds belonging to a space group $\mathrm{P6}_{3} / \mathrm{mmc}$ (194) Homawalt 1956

Due to the resemblance of ionic radii of $\mathrm{Fe}^{+3}$ with $\mathrm{Co}^{+3}$ and $\mathrm{Al}^{+3}$ ions $[13,14]$. The ferrites ions will replace by cobalt and aluminium. It is seen that former ions are very easily replaced at any substituted variation in all specimens [15]. The hexagonal lattice parameters ' $a$ ' and 'c' decreases linearly with the substitutional variation $\mathrm{co}^{+3}$ and $\mathrm{Fe}^{+3}$ concentration in all specimens. The decrease in lattice parameters due to close packing of lattices in the materials [16-18]. The decrease in lattice parameter and cell volume agree with result for $\mathrm{Ba} / \mathrm{Sr}$ ferrite [19-20]. The numerical values of compositional data such as lattice constant, cell volume and Xray density are tabulated in table -1 . The observed value of electrical conductivity, activation energy and curie molar constant for specimens are also tabulated in table - 2

The plot of $\ln \sigma$ vs $(1 / \mathrm{T}) \times 10^{-3} \mathrm{~K}$ for the entire sample was almost linear. The electrical conductivity of these ferrites increases with increasing ferrite ion concentration. The electrical conductivity of sintered specimens varies from to 
$2.193 \times 10^{12} \Omega^{-1} \mathrm{~cm}$ to $5.78 \times 10^{-6} \Omega^{-1} \mathrm{~cm}$ of these ferrites. The other workers have obtained a conductivity value of $2 \times 10^{-2} \Omega^{-1} \mathrm{~cm}$ for Li-ferrite that obtained is $2.3 \mathrm{x}$ $10^{-6} \Omega^{-1} \mathrm{~cm}[21]$

In the present work the electrical conductivity value obtained for the compounds are $2.193 \times 10^{-12}$ to $5.78 \times 10^{-6} \Omega^{-1} \mathrm{~cm}$. The value of the conductivity may be partly attributed to the low evaporation of lithium from the sample prepared different from these of Rozlescu etal 1974 and Venugopal Reddy 1981.The variation of activation energy with the substitutional variable parameters $\mathrm{x}$-may be explain on the basis of Vewrway model [22-24], a small number of ferrous ions $\left(\mathrm{Fe}^{+2}\right)$ are generally developed during sintering process which lead the conductivity in ferrites suggesting the hopping mechanism according $\left(\mathrm{Fe}^{+2}-\mathrm{Fe}^{+3}+\mathrm{e}^{-}\right)[25,28]$. However these transition take place for a very small interval of time and are not detectable by the ordinary method.This valence exchange mechanism of Verwey may be considered for these ferrites as general applicable to M-type ferrite.

Table 1: Consolidated structural data of lithium ferrites

\begin{tabular}{|l|c|c|c|c|c|}
\hline \multirow{2}{*}{ Compounds } & \multicolumn{2}{|c|}{ Lattice parameters } & Cell Volume $\left(\mathrm{A}^{0}\right)^{3}$ & $\begin{array}{l}\text { Mol. Wt } \\
\mathrm{gm}\end{array}$ & $\begin{array}{l}\text { X-Ray Density } \\
\text { gm/cc }\end{array}$ \\
\cline { 2 - 3 } & $a\left(\mathrm{~A}^{0}\right)$ & $\mathrm{c}\left(\mathrm{A}^{0}\right)$ & & & \\
\hline $\mathrm{Li}_{0.5} \mathrm{Fe}_{2 .} \mathrm{Al}_{8} \mathrm{Co}_{2} \mathrm{O}_{19}$ & 5.859 & 22.323 & 663.81 & 780.89 & 3.9065 \\
\hline $\mathrm{Li}_{0.5} \mathrm{Fe}_{6.5} \mathrm{Co}_{6} \mathrm{O}_{19}$ & 5.695 & 21.262 & 597.22 & 1024.42 & 5.6963 \\
\hline
\end{tabular}

Table 2 : DC conductivity parameters of compounds

\begin{tabular}{|l|c|c|c|}
\hline Compounds & $\begin{array}{c}\text { Electrical Resistivity at } \\
\text { room temperature. } \\
\Omega \mathrm{cm}^{-1}\end{array}$ & $\begin{array}{c}\text { Activation energy } \\
\mathrm{E} \mathrm{in}(\mathrm{eV})\end{array}$ & $\begin{array}{c}\text { Electrical Conductivity } \\
\text { at room temperature. } \\
\Omega^{-1} \mathrm{~cm}\end{array}$ \\
\hline $\mathrm{Li}_{0.5} \mathrm{Fe}_{2.5} \mathrm{Al}_{8} \mathrm{Co}_{2} \mathrm{O}_{19}$ & $4.559 \times 10^{11}$ & 0.77 & $2.193 \times 10^{-12}$ \\
\hline $\mathrm{Li}_{0.5} \mathrm{Fe}_{6.5} \mathrm{Co}_{6} \mathrm{O}_{19}$ & $1.72 \times 10^{5}$ & 0.39 & $5.78 \times 10^{-6}$ \\
\hline
\end{tabular}

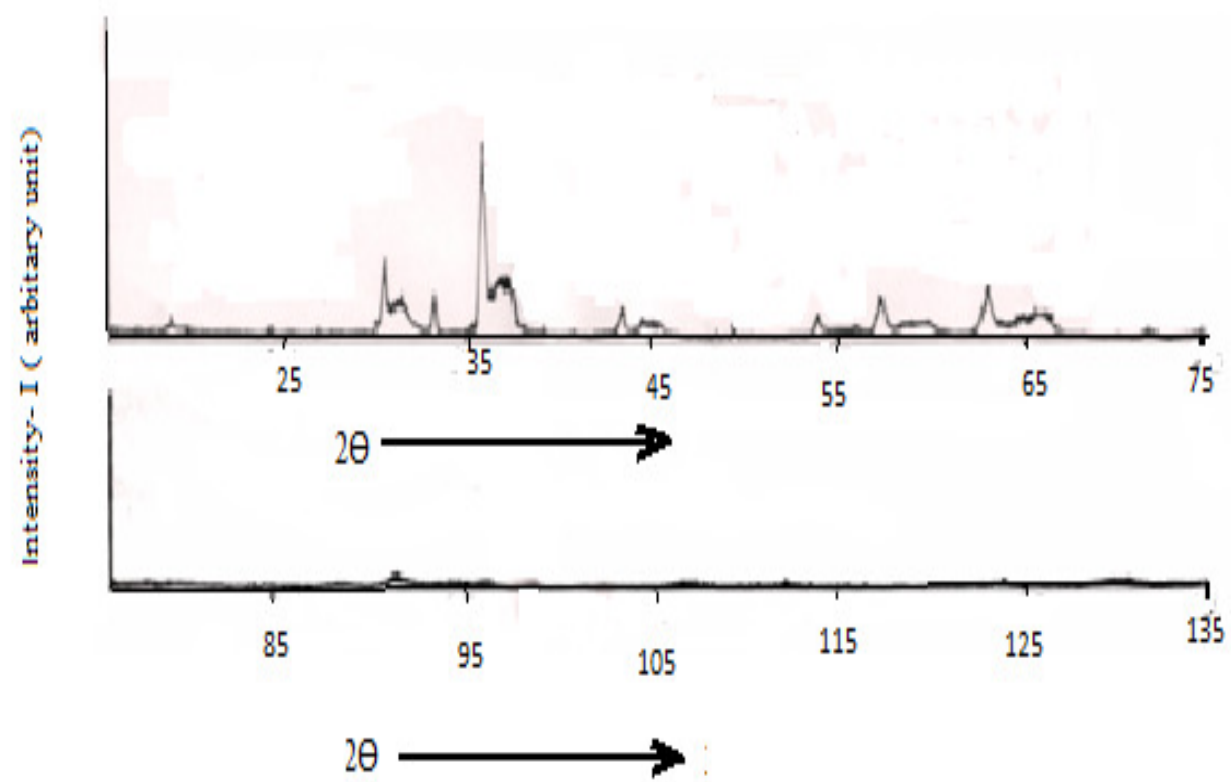




\section{Figure. 1: X-Ray diffraction pattern of $\mathrm{Li}_{0.5} \mathrm{Fe}_{2.5} \mathrm{Al}_{8} \mathrm{C}_{2} \mathrm{O}_{19}$}

\section{Conclusion:}

In the present work of lithium ferrites, is to check the formation of ferrite containing $\mathrm{Al}^{+3}$ and $\mathrm{Co}^{+3}$ ions along with $\mathrm{Fe}^{+3}$ ions. All these compounds have $\mathrm{M}-$ structure through the site distribution changes. No changes occur in the charge distribution but the site distribution is change due to strichiometric changes.

\section{Acknowledgement:}

Author is thankful to UGC, New Delhi for providing financial assistance to carried out this Work under minor research project scheme.

\section{References:}

1. J.Beretea and T.Brown.Austral.J.Chem.24(1971) 273

2. J.Lipka,A. Gruskova, O.Orlicky, J.Siteck, M.Miglierini, R.Grone, M.Hud and Toth Hyperfine Interaction 59(1990) 381.

3. G.Albanese, A Deriu, E.Luchini and G.Slokar.Appli Phys A 2(1981) 45

4. R.Muller, H.Pfeiffer and W.Schuppet, J.Mogn.Mogn Mater 18 (1991) 101

5. D.K.Kulkarni and C.S.Prakash Bull Mater Sci.17(1994) 35

6. G.Asti. M.Carbuccocchio. A Deriu, E.Lucchini and G.Slokar, J.Mogn mogn Mater 20(1980) 44

7. J.G.Renson, J.A.Schullces and J.S.Van.WIering, J.Phys Collog 32(1971) C 1-924

8. B.X.Gu, H.Y.Zang. H.R.Zhai, B.G.Slen, M.Lu, S.Y.Zhang and Y.Z.Maoi, Phys State Sol 133 (1992) K83

9. Hanmawalt(1936) International table for X-ray diffraction photograph

10. X.Obrador, A Isalgue,A Collomb, A Tejeda, J.C.Joubert, J.,PhysC. 19(1986) 6605

11. D.B.Ghare, A.P.B.Sinha, J.Phys Chem Solid 29(1958) 885

12. K.Haneda, H.Kojima. Phys State Solid (A) 6(1971) 256

13. .Kanke E, Takayama Muromachi Y.Uchida, Kato and S. Takikawa, J.Solid state Chem 95(1991) 43

14. L.G.Van Uitert, J. Appl. Phys 28.1 (1957)317

15. C.S.Prakash and D.K.Kulkarni Ind J.Appl.Phys 32(1994) 368

16. K.G.Rewatkar, C.S.Prakash and D.K.Kulkarni Mater Sci.Lett 28(1995) 365

17. A. Isalgue, A Laberta, J.Tejada, X Obradir. Appl.Phys A39(1986) 221

18. S.S.Darokar, K.G.Rewatkar and D.K.Kulkarni Mater Chem.Phys.56 (1998) 84-85

19. K. Haneda, M. Kojima, J. Appl. Phys 14.B(1973) 3760

20. V. Adelskod, Arkir Kemi Min Geo 12 A (1938) 1

21. Albense G, Carbulichhio and Deril A J.Phys Solid State: A 23 (1974) 351

22. Z.Redrigue, Obradors X, Labrata A, Tejeja.J.Pernet M. M.Solid Paul and J.Tholente, J. Phys Collog 149 (1988) 119

23. J.M.Verstegen D.T.J.Solid State Chem 1(1973) 468

24. E.J. Verway J.H, De-Bar.Pec.Trar.Chem Pay Bull 55 (1936) 531

25. N.Rezlescu, D.Condurachi, P.Petrarju and E.Lucca, J.A.M .Ceream Soc.57(1974)40

26. T. T..Fang, J.B.Hawan and F.S.Shiun, J.Mater ci Lett 11 (1992) 127

27. S.S.Darokar, K.G.Rewatkar,M.S.Chowkase and D.K.Kulkarni,Indian J. Phys 74A(2) (2000) 155-157

28. S.S. Darokar et.al, J. Adv. Appl. Sci. Research, 2013, 4(1): 173-177. 
Jan. 2015

Issue-3, Volume-I
ISSN No. (Online) 2347-517X

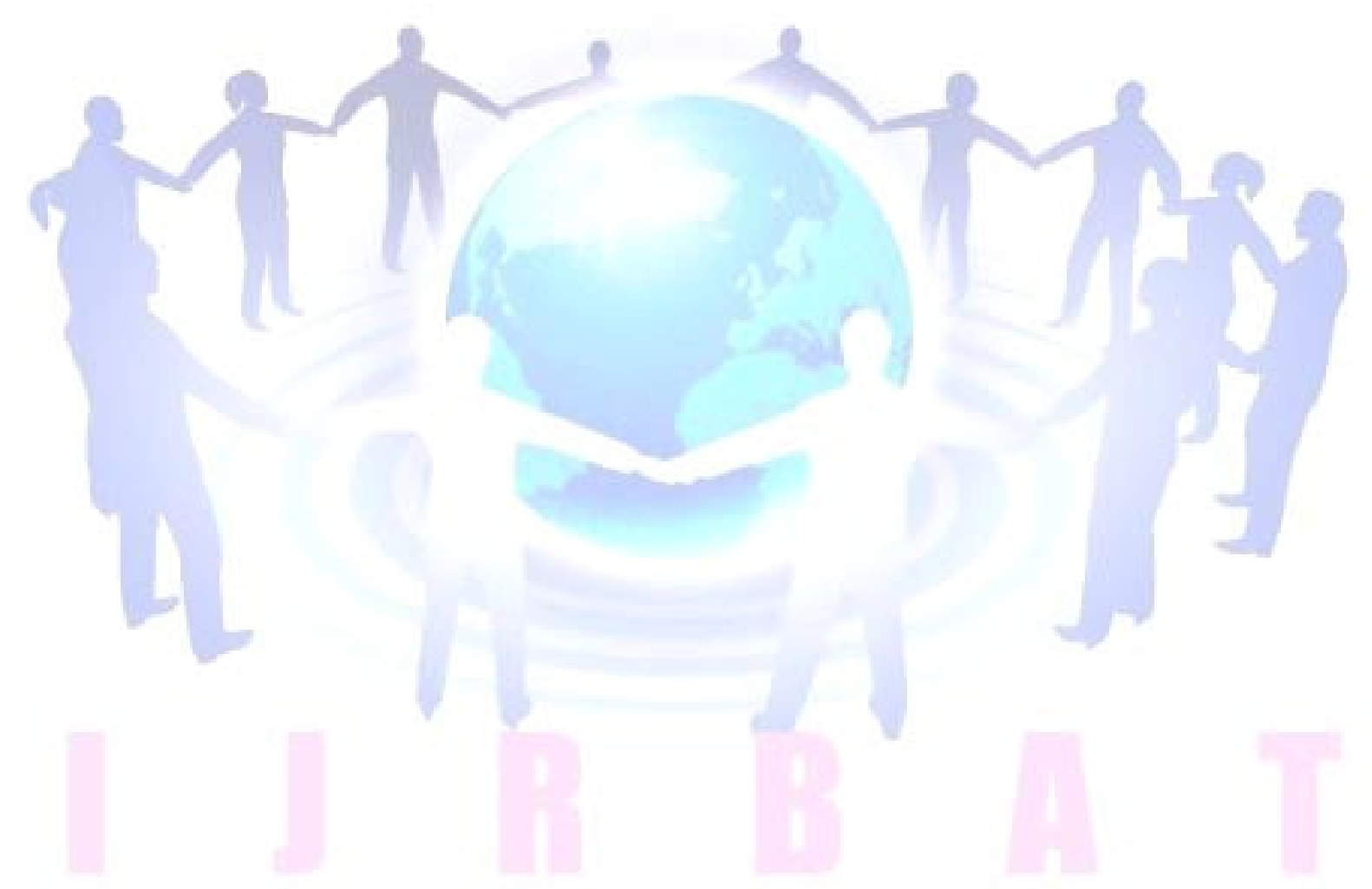

